\title{
TOXICOLOGICAL METHODS FOR TRACING DRUG ABUSE: CHROMATOGRAPHIC, SPECTROSCOPIC AND BIOLOGICAL CHARACTERISATION OF ECSTASY DERIVATIVES
}

\author{
Hafid BELHADJ-TAHAR ${ }^{1,2}$, Pierre PAYOUX ${ }^{2}$, Mathieu TAFANI ${ }^{2}$, Yvon COULAIS ${ }^{2}$, \\ Serge CALET $^{3}$, and Azzedine BOUSSEKSOU ${ }^{4}$ \\ Centre Anti-Poisons, CHU Purpan ${ }^{1}$, EA3033, Faculté de Médecine Université Paul Sabatier², \\ Laboratoire Holis Technologies ${ }^{3}$, CNRS, Laboratoire de Chimie de Coordination ${ }^{4}$, Toulouse, France
}

Received in January 2009

Accepted in September 2009

\begin{abstract}
Analysis often reveals variability in the composition of ecstasy pills from pure 3,4methylenedioxymethamphetamine (MDMA) to mixtures of MDMA derivatives, amphetamine, and other unidentified substances. For a comprehensive toxicological analysis one needs to know all steps to MDMA synthesis which may originate impurities. The aim of this study was to synthesise and determine the chemical-physical and in vitro biological properties of a series of MDMA derivatives.

3,4-methylendioxyphenyl-2-nitropropene (MDNP) was obtained by condensation of piperonal with an excess of nitroethane in the presence of ammonium acetate. MDNP was then reduced to methylenedioxyamphetamine (MDA) by $\mathrm{LiAlH}_{3}$. All compounds were analysed using HPLC and spectroscopic technique [Raman, nuclear magnetic resonance (NMR), or infrared (IR)] at all the steps of synthesis. In addition, we assessed the biological potentials of these compounds by measuring in vitro their (i) blood cell/whole blood partition coefficient, (ii) binding to plasmatic proteins (Fbp), and (iii) membrane adsorption. Chemical structure was determined with antibody fluorescence polarisation immunoassay (FPIA). This study showed the presence of solid impurities, particularly of a neurotoxic compound of $\mathrm{Al}^{3+}$ in the final products. FPIA identified the aminoethane group close to the substituted benzene ring, but did not detect the two major precursors of MDMA: MDNP and piperonal. Raman spectroscopy is an attractive alternative technique to characterise ecstasy pills and it can identify stereoisomeric forms such as cis-MDNP and trans-MDNP, which exhibit signals at $1650 \mathrm{~cm}^{-1}$ and $1300 \mathrm{~cm}^{-1}$, respectively.
\end{abstract}

KEY WORDS: IR, MDA, MDMA, MDNP, NMR, Raman, toxicology

Ecstasy is a synthetic drug used recreationally worldwide, especially by young people, which makes it a major public health concern (1). A recent French study with 1666 ecstasy pills carried out by a non-governmental organisation Rave Mission revealed that the pill composition varied from pure 3,4-methylenedioxymethamphetamine (MDMA) to a mixture of ecstasy derivatives, amphetamine, and $20 \%$ of other substances unidentified by Rapid
Product Control (RCP) (2). There are several possible ways to synthesise ecstasy, all of them starting with piperonal to obtain either a ketone (3,4-methylenedioxyphylpropanone) or an amine chemical form (3,4-methylenedioxyamphetamine) (2). Various impurities and by-products were identified in powdered tablets: 3,4-methylenedioxyamphetamine (MDA), MDA or MDMA dimers, substituted pyridines, lead, aluminium, and nitroethane $(3,4)$. 
Some of these compounds are toxic and could be involved in documented cases of fulminant toxic hepatitis and neurotoxic effects (4).

This suggests that a comprehensive toxicological analysis of an ecstasy pill requires expert knowledge of all synthetic steps and identification of impurities. Raman spectroscopy is a powerful technique to characterise ecstasy pills. In addition, it is an in situ, non-destructive technique that identifies chemical bonds through intramolecular vibration spectrum (5-7). The technique has proven successful in several published studies of illegal drugs $(8,9)$. In addition, Raman spectroscopy was used to probe photoexcitated phase transition with second irradiation using nanosecond pulsed laser leading for example to colour changes (10). These properties could be exploited to identify organic metals in a sample.

The aim of our study was to first synthesise a series of MDMA derivatives, then to characterise them using HPLC and spectroscopic techniques [Raman, nuclear magnetic resonance (NMR), or infrared (IR)], and finally to establish their biological effects on blood cells, proteins, anisotropic polar membrane, and antibodies.

\section{MATERIALS AND METHODS}

\section{Chemicals}

Piperonal, lithium aluminium hydride $\left(\mathrm{LiAlH}_{3}\right.$, $1 \mathrm{~mol} \mathrm{~L}^{-1}$ in tetrahydrofuran), sodium borohydride $\left(\mathrm{NaBH}_{4}\right)$, ammonium acetate $\left[\left(\mathrm{NH}_{4}\left(\mathrm{CH}_{3} \mathrm{COO}\right)\right]\right.$, trifluoroacetic anhydride $\left[\left(\mathrm{CF}_{3} \mathrm{CO}\right)_{2} \mathrm{O}\right]$, nitroethane $\left(\mathrm{CH}_{3} \mathrm{CH}_{2} \mathrm{NO}_{2}\right)$, and other solvents (all of pro analysis grade) were purchased from Acros Organics (Geel, Belgium). All reagents were used without further purification.

\section{Synthesis}

The synthesis started with piperonal (11), which was dissolved with excess of nitroethane in the presence of ammonium acetate, leading to 3,4methylendioxyphenyl-2-nitropropene (MDNP). MDA was obtained by reducing MDNP with $\mathrm{LiAlH}_{3}$. Typically, MDNP was prepared by refluxing a mixture of $25 \mathrm{mmol}$ of piperonal $(3.75 \mathrm{~g}), 133 \mathrm{mmol}$ of nitroethane, $12.5 \mathrm{mmol}$ of ammonium acetate, and $60 \mathrm{~mL}$ of toluene. The mixture was heated overnight with continuous removal of water into a Dean-Starck tube. The solvent was then evaporated in vacuum and the residue re-crystallised from solvent mixture $\mathrm{CH}_{3} \mathrm{OH}: \mathrm{H}_{2} \mathrm{O}(1: 10)$.

Dropwise we carefully added $1.15 \mathrm{mmol}$ of $\mathrm{LiAlH}_{3}$ to $100 \mathrm{~mL}$ of the stirred solution of $0.05 \mathrm{~mol} \mathrm{~L}^{-1}$ MDNP in tetrahydrofuran. The resulting mixture was heated for five hours. $\mathrm{LiAlH}_{3}$ was decomposed by $\mathrm{H}_{2} \mathrm{O}$ and the solid was removed by filtration. MDA was dissolved in $20 \mathrm{~mL}$ of dichloromethane and washed with $500 \mathrm{~mL}$ of $1 \mathrm{~mol} \mathrm{~L}^{-1}$ sodium hydroxide solution.

To obtain 3,4-methylendioxyphenyl-2-nitropropane, we added $\mathrm{NaBH}_{4}(0.02 \mathrm{~mol})$ to a solution of MDNP $(0.01 \mathrm{~mol})$ in methanol $(25 \mathrm{~mL})$ by stirring at $5{ }^{\circ} \mathrm{C}$ to $10{ }^{\circ} \mathrm{C}$. After allowing the reaction to continue for another hour at room temperature, the mixture was concentrated. Excess of $\mathrm{NaBH}_{4}$ was decomposed with acetic acid and extracted with chloroform.

\section{CHARACTERISATION}

\section{HPLC}

The precursor and final products were determined by HPLC equipped with a UV detector. The mobile phase consisted of methanol: $\mathrm{H}_{2} \mathrm{O}$ :trifluoroacetic acid (60:40:0.01). Eluation was in isocrat mode at the flow rate of $1 \mathrm{~mL} \mathrm{~min}{ }^{-1}$. HPLC separation was performed on a reverse-phase $\mathrm{C}_{18}$ column (LiChrospher 60, RP-select B ,125 mm x $4 \mathrm{~mm}$, with $5 \mu \mathrm{m}$ sized particles).

\section{NMR spectroscopy}

${ }^{1} \mathrm{H}$ and ${ }^{13} \mathrm{C}$ NMR spectra were acquired at $250.13 \mathrm{MHz}$ on a Bruker WM250 spectrometer. Chemical shifts are given in ppm $v$ s. tetramethylsilane (TMS, ${ }^{1} \mathrm{H}$ and ${ }^{13} \mathrm{C}$ ) using $\left(\mathrm{CD}_{3}\right)_{2} \mathrm{SO}$ as solvent $\left(\mathrm{d}^{1} \mathrm{H}=2.62 \mathrm{ppm}\right.$ and $\left.\mathrm{d}^{13} \mathrm{C}=39.6 \mathrm{ppm}\right)$.

\section{Raman spectroscopy}

Spectra were acquired using a Dilor XY1800 triplemate spectrograph coupled to a Princeton Instruments CCD detector. The $647.1 \mathrm{~nm}$ line of a $\mathrm{Kr}^{+}$laser (Coherent Radiation Innova) was used as the excitation source with laser power of $50 \mathrm{~mW}$. Raman signals were collected at room temperature, at $180^{\circ} \mathrm{C}$ to the incident laser beam in the $170 \mathrm{~cm}^{-1}$ to $2400 \mathrm{~cm}^{-1}$ frequency range. Rayleigh scattering was removed using a holographic notch filter. 


\section{Infrared spectroscopy}

IR spectra were recorded on $\mathrm{KBr}$ discs with a Perkin-Elmer 983 spectrometer. For all the studied compounds we scanned four accumulations between $400 \mathrm{~cm}^{-1}$ and $4000 \mathrm{~cm}^{-1}$ with $2 \mathrm{~cm}^{-1}$ resolution.

\section{Biological characterisation}

The biological potentials of compounds were assessed from in vitro measurements of their fraction bound to plasma proteins coefficient $\left(\mathrm{F}_{\mathrm{bp}}\right)$, determination of blood cell/whole blood partition coefficient $\left(\mathrm{F}_{\mathrm{cb}}\right)$, membrane adsorption coefficient $\left(\mathrm{F}_{\mathrm{ad}}\right)$, and interaction with specific anti-MDMA antibody. These biological methods were described elsewhere (12).

\section{Determination of $F_{b p}$}

$200 \mu \mathrm{L}$ of plasma spiked with the studied compound $\left(0.1 \mathrm{nmol} \mathrm{L}^{-1}\right)$ was incubated in a water bath at $37^{\circ} \mathrm{C}$ for $15 \mathrm{~min}$ and placed in an ultrafiltration cell. After centrifugation in an SM24 centrifuge (Dupont Instruments; Wilmington, DE, USA) at $1978 \mathrm{~g}$ for $20 \mathrm{~min}$, the ultrafiltrate was analysed using HPLC. The unbound to protein fraction $\left(\mathrm{F}_{\text {up }}\right)$ was determined by calculating the ratio of the concentration in ultrafiltrate and the initial compound concentration in plasma. The fraction bound to plasma proteins was deducted from the following equation: $\mathrm{F}_{\mathrm{bp}}=100 \%-\mathrm{F}_{\mathrm{up}}$.

\section{Determination of $F_{c b}$}

$20 \mu \mathrm{L}$ of physiological solution of each compound at concentration of $1 \mathrm{mmol} \mathrm{L}^{-1}$ was added to $2 \mathrm{~mL}$ fresh blood taken on EDTA tripotassium salt ( $\mathrm{K}_{3}$ EDTA). After incubation for $15 \mathrm{~min}$ at $37^{\circ} \mathrm{C}$, the blood sample was centrifuged (at $2000 \mathrm{~g}$ for $15 \mathrm{~min}$ ) and $200 \mu \mathrm{L}$ plasma were taken to determine the concentration in the ultrafiltrate (see determining $\mathrm{F}_{\mathrm{bp}}$ above). Calculations were performed using the following equation:

$$
\mathrm{F}_{\mathrm{cb}}=\left[\mathrm{C}_{\mathrm{bt}}-\left(\mathrm{C}_{\mathrm{uf}} / \mathrm{F}_{\mathrm{up}}\right)\right] /\left[\mathrm{C}_{\mathrm{bt}} \mathrm{h}\right]
$$

The free fraction, which is neither bound to blood cells nor to proteins, was determined using the following equation:

$$
\mathrm{F}_{\mathrm{fr}}=\left(1-\mathrm{F}_{\mathrm{cb}}\right)\left(1-\mathrm{F}_{\mathrm{bp}}\right)
$$

where $\mathrm{F}_{\mathrm{cb}}$ is the blood cell/whole blood partition coefficient; $\mathrm{C}_{\mathrm{bt}}$ the concentration in total blood $\left(0.01 \mathrm{mmol} \mathrm{L}^{-1}\right) ; \mathrm{C}_{\mathrm{uf}}$ the concentration in ultrafiltrate; $\mathrm{F}_{\text {up }}$ the unbound-to-protein fraction coefficient; $\mathrm{h}$ is haematocrit; $\mathrm{F}_{\mathrm{bp}}$ binding to plasma proteins coefficient, and $\mathrm{F}_{\mathrm{fr}}$ the free fraction coefficient.

\section{Determination of $F_{a d}$}

$200 \mu \mathrm{L}$ of physiological solution of each compound $\left(1 \mu \mathrm{mol} \mathrm{L}^{-1}\right)$ were centrifuged through permeable anisotropic membrane (Amicon) at $1978 \mathrm{~g}$ for $20 \mathrm{~min}$ (SM24 centrifuge, Dupont Instruments; Wilmington, DE, USA) and the ultrafiltrate was analysed using HPLC. The coefficient of membrane adsorption was estimated using the following equation:

$$
\mathrm{F}_{\mathrm{ad}}=\left[\mathrm{C}_{\mathrm{is}}-\mathrm{C}_{\mathrm{su}}\right] / \mathrm{C}_{\mathrm{is}} \text {, }
$$

where $\mathrm{F}_{\mathrm{ad}}$ is the membrane adsorption coefficient; $\mathrm{C}_{\text {is }}$ the concentration in initial physiological solution; and $\mathrm{C}_{\mathrm{su}}$ the concentration in the ultrafiltrate.

\section{Interaction with specific anti-MDMA antibody}

Physiological solution of each compound $\left(0.01 \mathrm{mmol} \mathrm{L}^{-1}\right)$ was analysed using an automated FPIA system (Abbott AxSYM ${ }^{\circledR}$, USA).

\section{RESULTS AND DISCUSSION}

In this study, we have described the synthesis route starting from piperonal and ending with 3,4methylenedioxyamphetamine (MDA) (11). We have also reported the synthesis of 3,4 methylendioxyphenyl2-nitropropane, which is not considered precursor of MDMA. We used 3,4 methylendioxyphenyl-2nitropropane to study its interaction with specific anti-MDMA antibody.

MDNP and MDA were obtained with high chemical purity. The synthesis reactions were followed by HPLC determination of retention times of the obtained products. Piperonal, MDA and MDNP exhibited high lipophilicity (Figure 1). The retention

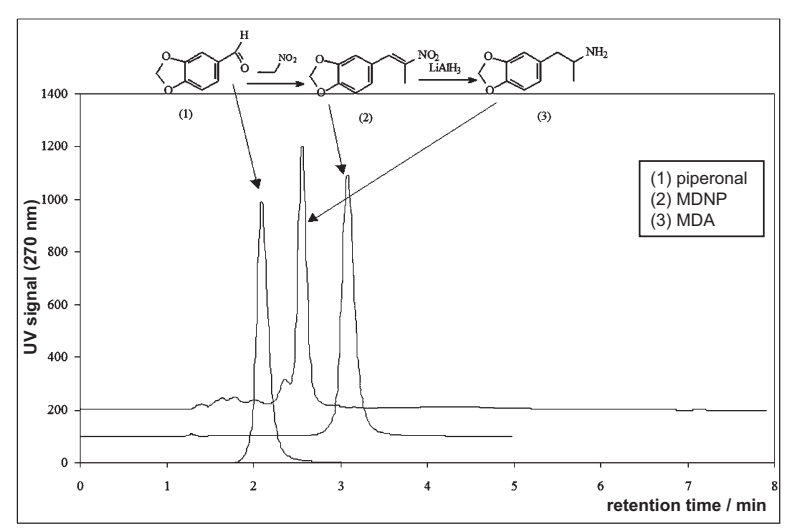

Figure 1 HPLC patterns of piperonal and synthesised MDNP and $M D A$ 
times of piperonal, MDA, and MDNP were $2 \mathrm{~min}$, $2.5 \mathrm{~min}$, and $3.1 \mathrm{~min}$, respectively, and correlated to their lipophilicity (13).

IR and NMR spectroscopies showed a clear profile of piperonal, MDNP, and MDA. NMR detected the following signals:

${ }^{1} \mathrm{H}$ NMR: $\mathrm{d}=1.22\left(\mathrm{~d}, \mathrm{~J}=6.2 \mathrm{~Hz}, 3 \mathrm{H}, \mathrm{CH}_{3}\right), 2.71$ (dd, $\mathrm{J}=13.4$ and $\left.8.8 \mathrm{~Hz},{ }^{1} \mathrm{H}, \mathrm{CH}_{2}\right), 3.07$ (dd, J=13.4 and $\left.5.2 \mathrm{~Hz},{ }^{1} \mathrm{H}, \mathrm{CH}_{2}\right), 3.43\left(\mathrm{~m},{ }^{1} \mathrm{H}, \mathrm{CH}\right), 6.10(\mathrm{~s}, 2 \mathrm{H}$, $\left.\mathrm{CH}_{2}\right), 6.80\left(\mathrm{dd}, \mathrm{J}=7.8\right.$ and $\left.1.3 \mathrm{~Hz},{ }^{1} \mathrm{H}, \mathrm{C}_{4} \mathrm{H}\right), 6.97(\mathrm{~d}$, $\left.\mathrm{J}=1.3 \mathrm{~Hz},{ }^{1} \mathrm{H}, \mathrm{C}_{6} \mathrm{H}\right), 6.97\left(\mathrm{~d}, \mathrm{~J}=7.8 \mathrm{~Hz},{ }^{1} \mathrm{H}, \mathrm{C}_{3} \mathrm{H}\right)$.

${ }^{13} \mathrm{C}$ NMR: $17.6\left(\mathrm{CH}_{3}\right), 39.7\left(\mathrm{CH}_{2}\right), 48.2(\mathrm{CH})$, $101.0\left(\mathrm{CH}_{2}\right.$ dioxole $), 108.4\left(\mathrm{C}_{3} \mathrm{H}\right), 109.6\left(\mathrm{C}_{6} \mathrm{H}\right), 122.5$ $\left(\mathrm{C}_{4} \mathrm{H}\right), 130.6\left(\mathrm{C}_{5}\right), 146.1\left(\mathrm{C}_{1}\right), 147.5\left(\mathrm{C}_{2}\right)$.

IR (Figure 2) revealed signals related to benzene ring (absorption at $1603 \mathrm{~cm}^{-1}, 1505 \mathrm{~cm}^{-1}, 1680 \mathrm{~cm}^{-1}$, and $1489 \mathrm{~cm}^{-1}$ ), to ether oxide bridge at $1489 \mathrm{~cm}^{-1}$, and to MDMA derivatives.

For piperonal, the band located at $1677 \mathrm{~cm}^{-1}$ revealed the presence of aldehyde, for MDNP the band at $1510 \mathrm{~cm}^{-1}$ indicated a nitro compound in position alpha of an unsaturated bond, and MDA was characterised by bands at $3358 \mathrm{~cm}^{-1}$ and $1634 \mathrm{~cm}^{-1}$ pointing to amines, and by the disappearance of the nitro signals.

Figure 2 shows the vibrational modes of piperonal, MDNP, and MDA plotted in the range of $250 \mathrm{~cm}^{-1}$ to $1750 \mathrm{~cm}^{-1}$. While piperonal and MDNP showed high quality Raman spectra (Figure 3), MDA showed a spectrum with a rather large background, possibly due to a fluorescence in the system at either $632 \mathrm{~nm}$ or $541 \mathrm{~nm}$ (Figure 4). Milhazes et al. (9) obtained MDA spectrum at $541 \mathrm{~nm}$.

Table 1 lists the biological characteristics of the ecstasy derivatives and impurities in the final product. Of solid impurities found, a neurotoxic compound of $\mathrm{Al}^{3+}$ is of particular interest (4). Save for $\mathrm{F}_{\mathrm{bp}}$, all other biological parameters seem to be proportional to their retention time determined by HPLC and to their lipophilicity. Retention times for piperonal was $2 \mathrm{~min}$, for MDA and $2.5 \mathrm{~min}$, and for MDNP $3.1 \mathrm{~min}$ and corresponded to $\mathrm{F}_{\mathrm{ad}}$ and $\mathrm{F}_{\mathrm{b}}$.

Table 1 shows that the percent of free compounds in plasma is less than $40 \%$ of total blood concentration: $\mathrm{F}_{\mathrm{fr}}=23 \%$ for piperonal, $\mathrm{F}_{\mathrm{fr}}=27 \%$ for MDA, and $\mathrm{F}_{\mathrm{fr}}=38 \%$ for MDNP.

FPIA antibody recognised the aminoethane group close to the substituted benzene ring, but did not detect the two major precursors of MDMA, that is, MDNP and piperonal (Figure 5). This limitation must be taken into consideration, as detection of all ecstasy
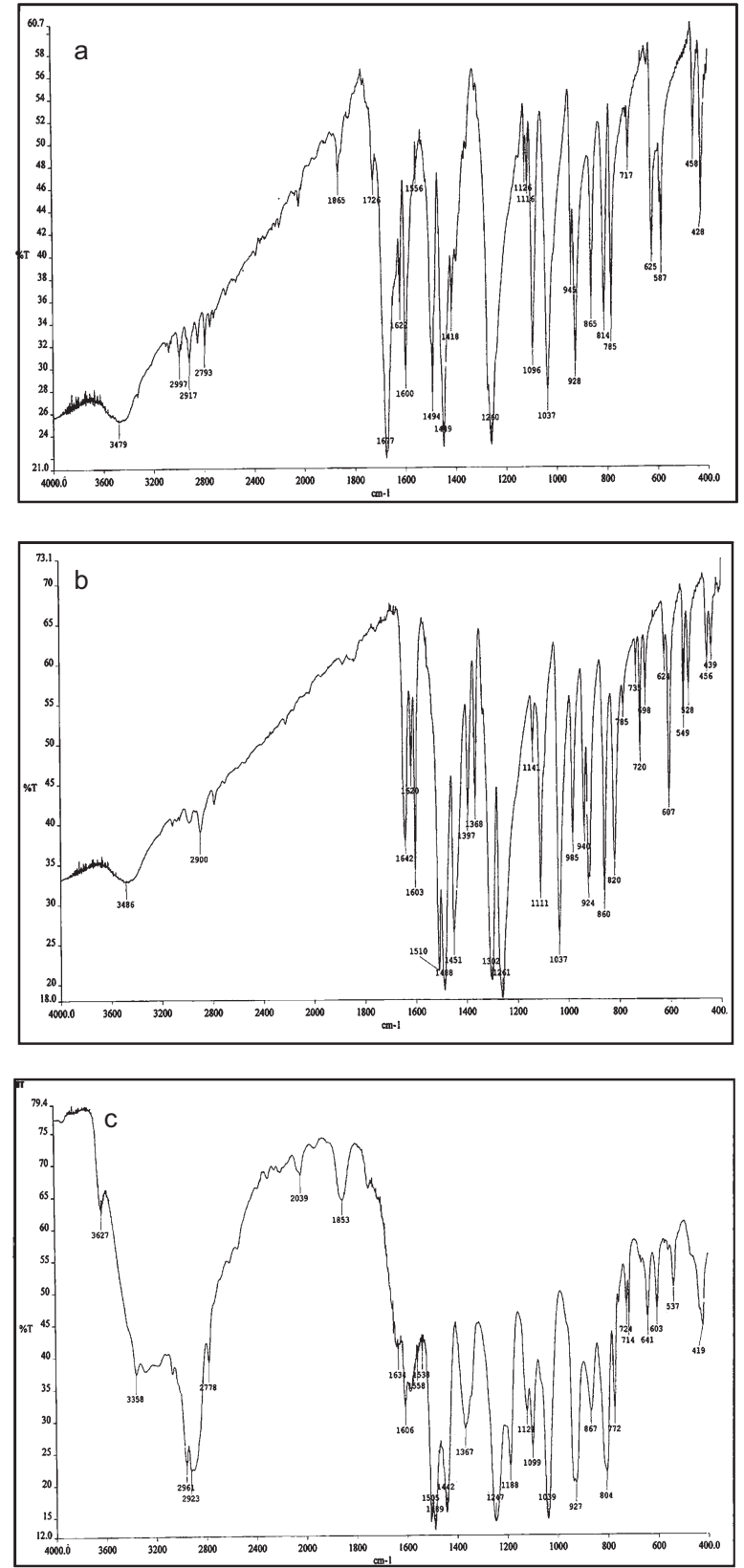

Figure 2 Infrared spectra of (a) piperonal, (b) MDNP, and (c) $M D A$

derivatives is required to optimise performance of detection methods.

\section{CONCLUSION}

This study has detected solid impurities and by-products in the synthesised products: MDA, unreacted piperonal, MDNP, and aluminium. While HPLC, Raman, and IR spectroscopy identified ecstasy derivatives, FPIA did not detect MDNP and piperonal. 

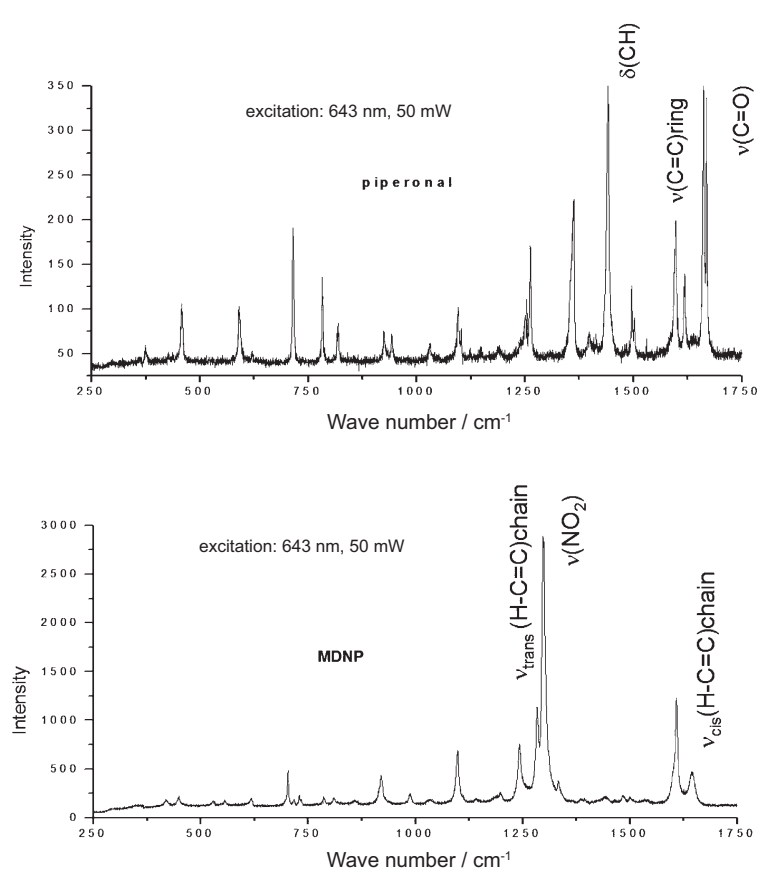

Figure 3 Raman spectra of piperonal and MDNP

Raman spectroscopy has turned out to be a particularly interesting alternative technique for characterising ecstasy pills, as it can determine stereoisomeric forms of compound such as cis-MDNP and trans-MDNP at $1650 \mathrm{~cm}^{-1}$ and $1300 \mathrm{~cm}^{-1}$, respectively.

Our findings call for further study of Raman spectroscopy to better characterise other drug derivatives.

\section{Acknowledgements}

This work was supported by Association Française de Promotion de la Recherche Médicale (AFPReMed). The authors thank Ms Aurore Palmaro for help in editing the text.

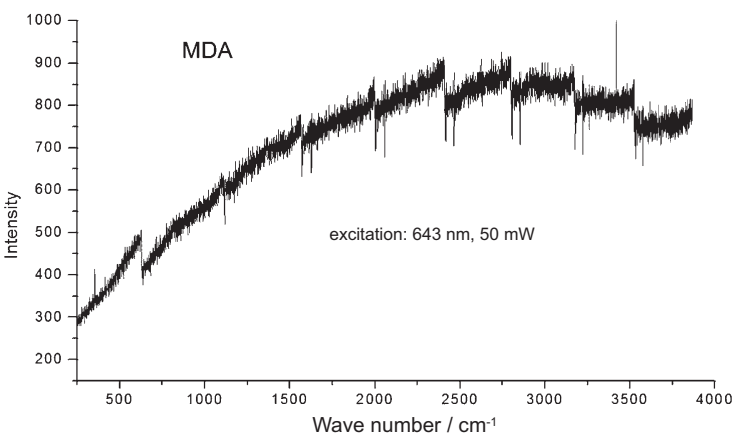

Figure 4 Raman spectrum of $M D A$<smiles>O=Cc1ccc2c(c1)OCO2</smiles>

(1)
FPIA-<smiles>CC(=Cc1ccc2c(c1)OCO2)[N+](=O)[O-]</smiles>

(2)<smiles>CC(Cc1ccc2c(c1)OCO2)[N+](=O)[O-]</smiles>

(3)
FPIA+<smiles>CC(N)Cc1ccc2c(c1)OCO2</smiles>

(4)
Figure 5 Molecules tested in vitro with fluorescence polarization immunoassay (FPIA). (1) piperonal; (2) MDNP; (3) 3,4-methylendioxyphenyl-2-nitropropane; and (4) $M D A$.

\section{REFERENCES}

1. Leung KS, Cottler LB. Ecstasy and other club drugs: a review of recent epidemiologic studies. Curr Opin Psychiatry 2008;21:234-41.

2. Belhadj-Tahar H, Molnar Y, Payoux P, Coulais Y, Costes JP, Robert L, Esquerre JP, Bousseksou A. Contribution of the Raman spectroscopy in the characterization of ecstasy derivatives. In: $40^{\text {th }}$ International Meeting of The International Association of Forensic Toxicologists (TIAFT), Paris, France, August 26-30 ${ }^{\text {th }}$ Paris: TIAFT; 2002.

Table 1 Biological characteristics of ecstasy derivatives and impurities in the final product

\begin{tabular}{lcccccc}
\hline & $\mathbf{F}_{\mathbf{b p}} / \mathbf{\%}$ & $\mathbf{F}_{\mathbf{c b}} / \mathbf{\%}$ & $\mathbf{F}_{\mathbf{f r}} / \boldsymbol{\%}$ & $\mathbf{F}_{\mathbf{a d}} / \mathbf{\%}$ & Derivatives and impurities & FPIA \\
\hline Piperonal & 63 & 38 & 23 & 47 & & Negative \\
MDNP & 88 & 68 & 38 & 90 & Piperonal $^{(\mathrm{s})}, \mathrm{Toluene}^{(1)}, \mathrm{NH}_{4} \mathrm{Ac}^{(\mathrm{s})}, \mathrm{EtNO}_{2}{ }^{(1)}$ & Negative \\
MDA & 71 & 30 & 27 & 63 & $\mathrm{MDNP}^{(\mathrm{s})}, \mathrm{THF}^{(1)}, \mathrm{Al}^{3+(\mathrm{s})}$ & Positive \\
\hline
\end{tabular}

(l) liquid; (s) solid

MDNP: 3,4-methylendioxyphenyl-2-nitropropene; MDA: 3,4-methylenedioxyamphetamine; FPIA: fluorescence polarization immunoassay; $F_{b p}$ : blood cell/whole blood partition coefficient; $F_{f r}:$ free fraction coefficient; $F_{c b}$ : binding to plasmatic proteins coefficient; $F_{a d}:$ membrane adsorption coefficient; THF: tetrahydrofuran; $\mathrm{NH}_{4}$ Ac: ammonium acetate; EtNO ${ }_{2}$ : nitroethane 
3. Cheng JY, Chan MF, Chan TW, Hung MY. Impurity profiling of ecstasy tablets seized in Hong Kong by gas chromatography-mass spectrometry. Forensic Sci Int 2006;16:87-94

4. Belhadj-Tahar H, Houin G, Frances B, Molnar G, Zwick A, Bousseksou A, Costes JP, Esquerre JP, Coulais Y. Relationship between chemical structure of ecstasy and positive response to fluorescence polarisation immunoassay: Interest of ${ }^{1} \mathrm{H},{ }^{13} \mathrm{C}$ RMN, IR, and Raman spectrocopic methods [Relation entre structure chimique et positivité du dépistage de l'ecstasy par immunochimie FPIA: intérêt des spectroscopies ${ }^{1} \mathrm{H}, 13 \mathrm{C}$ RMN, IR et Raman, in French]. Annales de Toxicologie Analytique 2003;17:179-80.

5. Smith WE. Practical understanding and use of surface enhanced Raman scattering/surface enhanced resonance Raman scattering in chemical and biological analysis. Chem Soc Rev 2008;37:955-64.

6. Bell SE, Spence SJ. Disposable, stable media for reproducible surface-enhanced Raman spectroscopy. Analyst 2001;126:13.

7. Bousseksou A, McGarvey JJ, Varret F, Real JA, Tuchagues JP, Dennis AC, Boillot ML. Raman spectroscopy of the high- and low-spin states of the spin crossover complex $\mathrm{Fe}$ (phen)2(NCS)2: an initial approach to estimation of vibrational contributions to the associated entropy change. Chem Phys Lett 2000;318:409-16.

8. Bell SE, Fido LA, Sirimuthu NM, Speers SJ, Peters KL, Cosbey SH. Screening tablets for DOB using surface- enhanced Raman spectroscopy. J Forensic Sci 2007;52:10637.

9. Milhazes N, Martins P, Uriarte E, Garrido J, Calheiros R, Marques MP, Borges F. Electrochemical and spectroscopic characterisation of amphetamine-like drugs: application to the screening of 3,4-methylenedioxymethamphetamine (MDMA) and its synthetic precursors. Anal Chim Acta 2007;596:231-41.

10. Bonhommeau S, Molnár G, Galet A, Zwick A, Real JA, McGarvey JJ, Bousseksou A. One shot laser pulse induced reversible spin transition in the spin-crossover complex $[\mathrm{Fe}(\mathrm{C} 4 \mathrm{H} 4 \mathrm{~N} 2)\{\mathrm{Pt}(\mathrm{CN}) 4\}]$ at room temperature. Angew Chem Int Ed Engl 2005;44:4069-73.

11. Nichols DE, Hoffman AJ, Oberlender RA, Jacob P, Shulgin AT. Derivatives of 1-(1,3-benzodioxol-5-yl)-2-butanamine: representatives of a novel therapeutic class. J Med Chem 1986;29:2009-15.

12. Belhadj-Tahar H, Boumahdi R, Darbieu MH. Conceptionalization of diagnostic agents: From empirical in vivo screening to rational in vitro predictive parameters. Altern Lab Anim 2000;28:303-14.

13. Mrkvicková Z, Kovaríková P, Balíková S, Klimes J. Determination of lipophilicity of novel potential antituberculotic agents using HPLC on monolithic stationary phase and theoretical calculations. J Pharm Biomed Anal 2008;48:310-4. 


\section{Sažetak}

\section{TOKSIKOLOŠKE METODE OTKRIVANJA OPOJNIH DROGA U TRAGOVIMA: KROMATOGRAFSKA, SPEKTROSKOPSKA I BIOLOŠKA KARAKTERIZACIJA DERIVATA ECSTASYJA}

Analize često otkriju neujednačenost sastava tableta ecstasyja od čistoga 3,4-metilendioksimetamfetamina (MDMA) do mješavina njegovih derivata, amfetamina i drugih neutvrđenih tvari. Stoga je za kvalitetnu toksikološku analizu potreban uvid u sve korake sinteze MDMA, s obzirom na to da se ondje vjerojatno kriju izvori nečistoće (prekursori, katalizatori). Cilj ovog ispitivanja bio je sintetizirati derivate MDMA te napraviti njihovu kemijsko-fizikalnu i biološku in vitro karakterizaciju.

3,4-metilendioksifenil-2-nitropropen (MDNP) dobiven je kondenzacijom piperonala u suvišku nitroetana uz dodatak amonijeva acetata. Njegovom redukcijom s pomoću $\mathrm{LiAlH}_{3}$ dobiven je 3,4-metilendioksiamfetamin (MDA). Svi spojevi iz pojedinih koraka sinteze karakterizirani su s pomoću tekućinske kromatografije visoke djelotvornosti (HPLC) i spektroskopskih tehnika [Ramanove spektroskopije, nuklearne magnetske rezonancije (NMR-a) te infracrvene spektroskopije (IR-a)]. Usto je ocijenjen i njihov biološki učinak in vitro mjerenjem (i) koeficijenta raspodjele krvna stanica/puna krv, (ii) vezanja za bjelančevine u plazmi (Fbp) te (iii) adsorpcije na membranu. Kemijska je struktura utvrđena s pomoću fluorescentnoga polarizacijskog imunokemijskog testa (FPIA). Analiza je u konačnim proizvodima utvrdila prisutnost krutih nečistoća, napose spojeva neurotoksičnog aluminija $\left(\mathrm{Al}^{3+}\right)$. FPIA je prepoznao aminoetansku skupinu blizu supstituiranoga benzenskog prstena, ali ne i dva glavna prekursora za MDMA: MDNP i piperonal. Posebno je zanimljiva Ramanova spektroskopija budući da (i) pruža privlačnu alternativu za karakterizaciju sastava tableta ecstasyja te (ii) može otkriti stereoizomerne cis/trans-oblike spoja poput cis-MDNP-a odnosno trans-MDNP-a, čiji se signal vidi na $1650 \mathrm{~cm}^{-1}$ odnosno $1300 \mathrm{~cm}^{-1}$.

KLJUČNE RIJEČI: IR, MDA, MDMA, MDNP, NMR, Ramanova spektroskopija, toksikologija

\section{CORRESPONDING AUTHOR:}

\section{Dr Hafid Belhadj-Tahar}

Centre Antipoison et de Toxicovigilance

CHU-Purpan, 31059 Toulouse, France

E-mail: belhadj-tahar@afpremed.org 